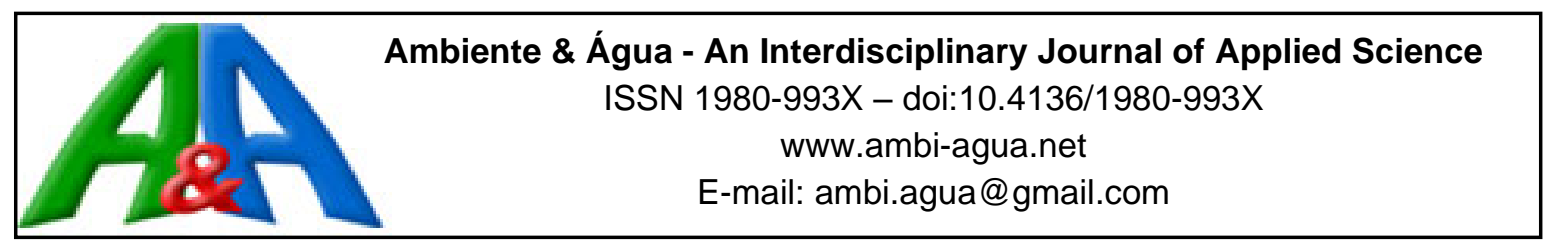

\title{
The use of artificial feed in Haliotis squamata farming in submerged cage culture system at Lae-Lae island, Makassar
}

\author{
ARTICLES doi:10.4136/ambi-agua.2719
}

Received: 31 Mar. 2021; Accepted: 10 Jun. 2021

\author{
Hadijah Hadijah $^{1 *}$; Mardiana Mardiana1 ${ }^{1 D}$; Erni Indrawati1 ${ }^{1(D)}$; \\ Sutia Budi ${ }^{1}$; Zainuddin Zainuddin² ${ }^{2}$ \\ ${ }^{1}$ Department of Aquaculture. Faculty of Agriculture. Bosowa University, 90231, Makassar, South Sulawesi, \\ Indonesia. E-mail: mardiana@universitasbosowa.ac.id, erni.indrawati@universitasbosowa.ac.id, \\ sutia.budi@universitasbosowa.ac.id \\ ${ }^{2}$ Faculty of Marine Sciences and Fisheries. Hasanuddin University, 90245, South Sulawesi, Indonesia. \\ E-mail: zainuddinlatief@gmail.com \\ *Corresponding author. E-mail: hadijahmahyuddin@gmail.com
}

\begin{abstract}
This study investigated the use of a combined formula of artificial feed and fresh marine algae Gracilaria sp in a submerged cage culture system and its effect on Haliotis squamata relative growth and survival rates. The experiment was performed in Lae-Lae Island, Makassar from May to October 2016. The sample Abalone juvenile larvae were $1.5 \mathrm{~cm}$ in size and stocked at a density of $30 \mathrm{pcs} / \mathrm{cage}$. The cage size was $30 \mathrm{~cm} \times 15 \mathrm{~cm} \times 7 \mathrm{~cm}$ and equipped with a 2inch Paralone pipe. This experiment employed a completely random design (CRD) with 3 treatments and 3 replicates. The applied treatment included the combination of artificial feed and fresh marine algae Gracilaria sp. Each treatment included: A. 25\% artificial feed $+75 \%$ fresh marine algae, B. 50\% artificial feed $+50 \%$ fresh marine algae, C. $75 \%$ artificial feed + $25 \%$ fresh marine algae, and was given at the proportion of $20 \%$ of the abalone's weight. The results of the study indicated that the use of a combined artificial feed with fresh marine algae (Gracilaria sp.) had no significant effect on relative growth and survival rates of Haliotis squamata. Although feed treatment did not significantly affect the relative growth and survival rate, descriptively, treatment $A$ contributed to the most optimal relative growth and the survival rate compared to treatments $\mathrm{B}$ and $\mathrm{C}$.
\end{abstract}

Keywords: abalone, Gracilaria sp, survival rate.

\section{O emprego de ração artificial na criação de Haliotis squamata cultivado em sistema de cultura em gaiola submersa na ilha de Lae- Lae, Makassar}

\section{RESUMO}

Este estudo tentou investigar o envolvimento de uma fórmula combinada de ração artificial e algas marinhas frescas Gracilaria $s p$ em um sistema de cultivo em gaiola submersa e seu efeito no crescimento relativo de Haliotis squamata e nas taxas de sobrevivência. $O$ experimento foi realizado na Ilha Lae-Lae, Makassar a partir de 2016. As larvas juvenis de Abalone da amostra tinham 1,5 cm de tamanho e foram estocadas a uma densidade de 30 unidades / gaiola. O tamanho da gaiola era de $30 \mathrm{~cm} \times 15 \mathrm{~cm}$ x $7 \mathrm{~cm}$ e equipado com um tubo 
Paralone de 2 polegadas. Este experimento empregou um delineamento inteiramente ao acaso (CRD) com 3 tratamentos e 3 repetições. O tratamento aplicado incluiu a combinação de ração artificial e algas marinhas frescas Glacilaria sp. Cada tratamento incluiu: A. $25 \%$ de ração artificial $+75 \%$ de algas marinhas frescas, B. $50 \%$ de ração artificial $+50 \%$ de algas marinhas frescas, C. $75 \%$ de ração artificial $+25 \%$ de algas marinhas frescas. Cada tratamento foi administrado na proporção de $20 \%$ do peso do abalone. Os resultados do estudo indicaram que o uso de um alimento artificial combinado com algas marinhas frescas (Gracilaria sp.) não teve efeito significativo no crescimento relativo e nas taxas de sobrevivência de Haliotis squamata. Embora o tratamento com ração não tenha afetado significativamente o crescimento relativo e a taxa de sobrevivência, significativamente, o tratamento A contribuiu para o crescimento relativo ideal e a taxa de sobrevivência em comparação com os tratamentos B e C.

Palavras-chave: abalone, Gracilaria sp, taxa de sobrevivência.

\section{INTRODUCTION}

The abalone Haliotis squamata is a species of sea snail or gastropod with a significant economic value (Ardi et al., 2020; Yun et al., 2020). These abalones are in great demand in countries such as Japan, the US, Europe, Columbia, and Canada (Cook, 2014; ABARES, 2017). This high demand is caused by abalone's low cholesterol content, rich nutrition, and delicacy (Grandiosa, 2020). In Japan, New Zealand, and Philippines, abalones are cultured (Grandiosa, 2020; Gallardo and Buen, 2003). In Indonesia, however, abalone fishing is heavily relied upon by local fishermen. Continuous, unregulated abalone fishing may eventually lead to population decline. Unfortunately, in Indonesia, this natural resource is not yet optimally utilized (Wuryandari, 2014). The abalone population decline was marked by the small size (Omar et al., 2006) and lower volume of catches (Hadijah and Zainuddin, 2007; 2008). Similar problems also occurred in other places, including California. In the last decade, such conditions contributed to the updated status of abalone population to an endangered species or critically endangered (Gruenthal, 2007). Although the status of the Indonesian abalone population is categorized as harvestable resources, continuous exploitation from fishing activities will eventually cause a population decrease. Therefore, one initiative to encourage abalone population conservation is abalone breeding. However, the effort of abalone conservation through breeding is still limited due to a number of factors, including feed availability and insufficiency of abalone larvae. To achieve abalone culture and conservation success, it is necessary to be attentive to the aspects of rearing, feeding, and sufficient larvae (Giri et al., 2015; Palumbi, 2003). To improve abalone production, breeding can be performed in submersible cages (Hadijah, 2017; Hadijah and Zainuddin et al. 2015; Li and Ong, 2017). Another challenge for marine abalone culture is the lack of information about good feed quality for abalone growth and survival. Generally, feeding macroalgae as a natural feed for abalone (Hadijah and Zainuddin, 2014; Hwang et al., 2014) would result in inefficient nutrition fulfillment (Kemp et al., 2015). However, some researchers have studied the use of macroalgae as a feed for abalones. According to (Bansemer et al., 2016; Chojnacka, 2012), feeding macroalgae to abalones could improve health, product quality, and feeding behavior of abalones compared to the formulated feed (Packer et al., 2016). On the other hand, live macroalgae feeding for abalone may cause another problem, considering its high moisture content capable of causing diseases and infection (Bautista-Teruel et al., 2003; Vandepeer, 2006).

Another research by (Hadijah, 2017; Hadijah, 2015) suggested that marine algae Gracilaria Sp contributed to the most optimal growth and survivability of tropical abalone compared to other types of feed. Unfortunately, the use of marine algae as natural feed in tropical abalone farming is considered to be inefficient due to the high feed ratio and resource 
reliance on seasonal algae harvesting. Based on those facts, this research focused on the implementation of artificial feed combined with fresh marine algae in marine abalone farming as an alternative effort to reduce artificial diet use.

\section{RESEARCH METHODS}

\subsection{Experimental and Culture Conditions}

Water quality parameters including water turbidity and depth were measured at the initial stage of the experiment. Water temperature measurement and feeding were performed simultaneously once every three days. The mean water temperature throughout the trial was sea-surface temperature $\left(27-28^{\circ} \mathrm{C}\right)$. Sea water salinity was measured by using a refractometer resulting in 32-33 ppm. The measurement of ocean currents was estimated using drifting floats. Phosphate and nitrate concentration in the water was collected both at the beginning and at the end of the experiment. Salinity and $\mathrm{pH}$ measurement was performed at different times. Dissolved oxygen was measured regularly in the morning and observed once every two weeks along with the in-situ abalone sampling. The experiment was conducted in Lae-Lae Island waters, Makassar, South Sulawesi, Indonesia, from May to October 2016. This study employed one-month-old abalone larvae (Haliotis squamata) with a 5-gram initial weight. The seeds were originally from the Bali Gondol Sea seed center and were transported to the site by airplane (a 10-hour trip). After arrival the seeds were acclimatized at the Takalar Brackish Water Seed Center for 24 hours. During the acclimatization, they were given fresh feed in the form of Gracilaria seaweed. The submersible cages for the abalone were made of a plastic rectangular vessel with small holes to enable the water flow. Easily obtained media to serve as abalone submersible cages were plastic containers designed to attach one another. To ensure the container's lid did not open, the two attached containers were locked using a $\mathrm{T}$ clip. These containers were stored in an iron cage with a size of $120 \mathrm{~cm} \mathrm{~L} \mathrm{x} 30 \mathrm{~cm} \mathrm{~W} \mathrm{x} 15 \mathrm{~cm} \mathrm{H}$. Each iron cage stored 4 plastic containers. There were 3 iron cages, and therefore 12 units of the plastic containers (Figure 1).

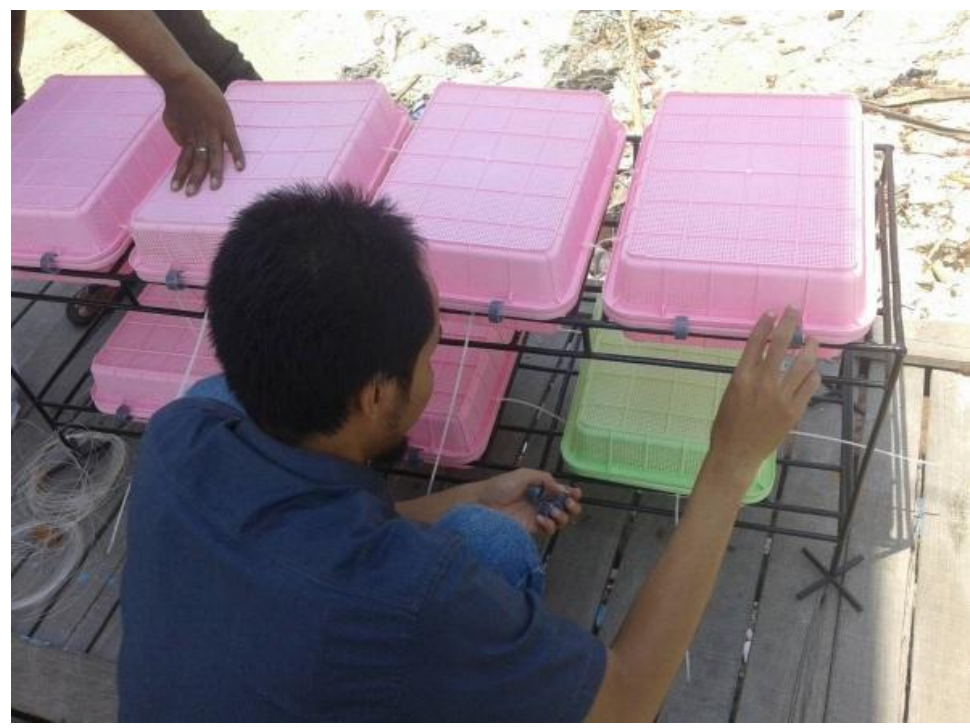

Figure 1. Abalone Rearing Containers.

A container with Abalone Juvenile larvae stocking density of 30 pcs/container (Figure 2).

Once all the containers were stocked with abalone larvae, the containers were attached to an iron rack and submerged (Figure 3). 


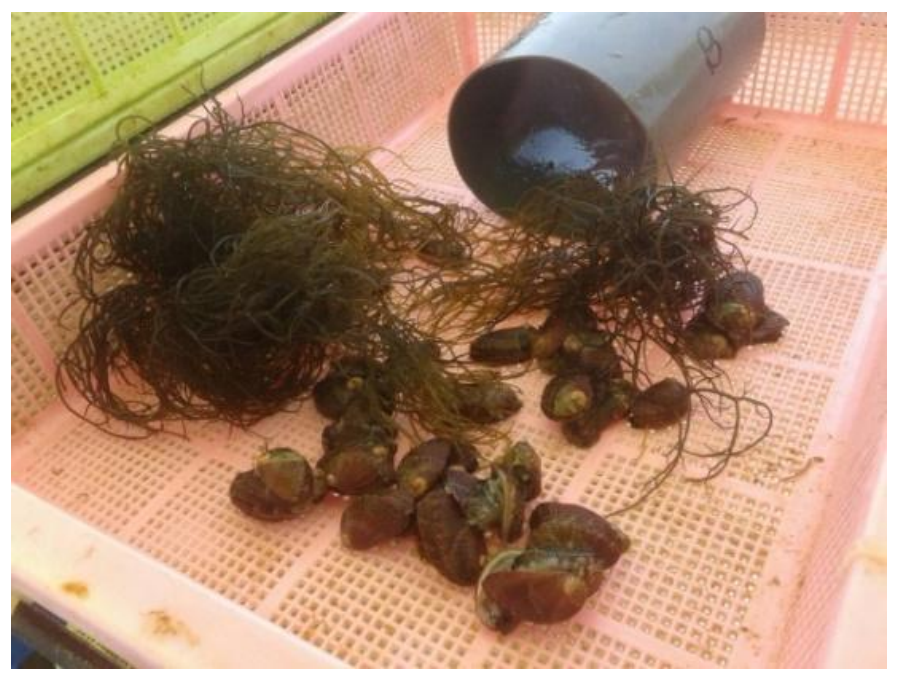

Figure 2. Abalone larvae were stocked in the container.

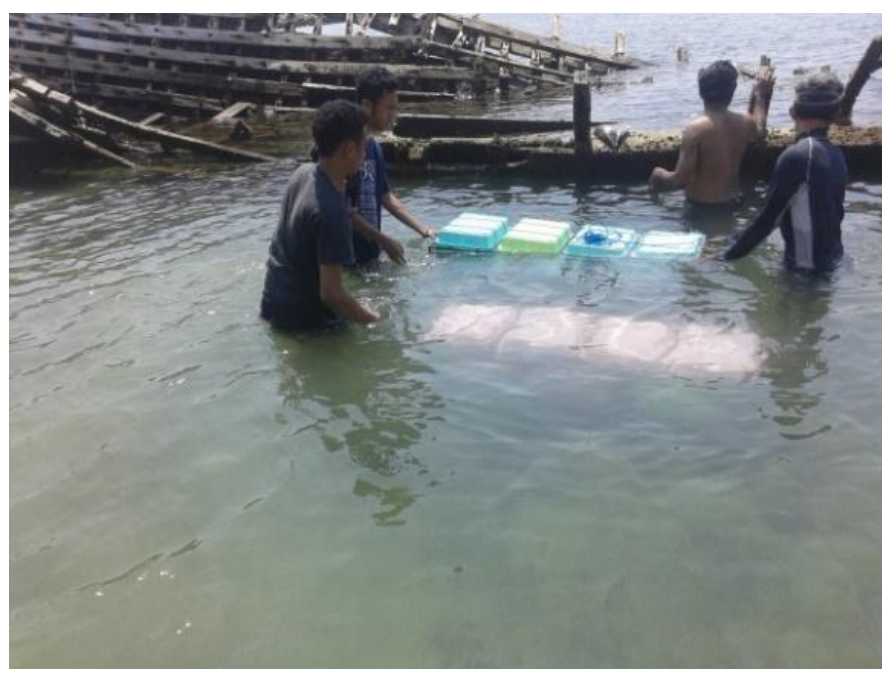

Figure 3. Positioning the containers with abalone larvae.

\subsection{Experimental diet and feeding}

The abalones were fed with a combination of artificial feed and fresh marine algae at a proportion of $20 \%$ abalone body weight. The experimental diet based on the treatment was randomly applied to the larvae rearing container (Bautista-Teruel and Millamena, 1999). Feedstuffs of artificial feed were composed of fish flour, corn starch, bran, wheat flour, starch as binder, vitamin mix and mineral mix (Table 1).

Table 1. The Composition of Formulated Feed for Abalone Larvae.

\begin{tabular}{ccc}
\hline $\mathrm{N}^{\circ}$ & Name Feedstuff & Percentage \\
\hline 1 & Local fish meal & 33 \\
2 & Bran flour & 17 \\
3 & Corn Starch & 10 \\
4 & Wheat Flour & 25 \\
5 & Starch & 11 \\
6 & Fish Oil & 2 \\
7 & Vit-Mix & 2 \\
\hline & Total & 100
\end{tabular}


Feed formulation was pelletized and dried until moisture content remained $10 \%$ and dry cracks appeared on the pellets. Proximate analysis was performed on the dried pelleted feed to identify the nutritional content in the formula. The results of the proximate analysis are presented in Table 2.

Table 2. Chemical composition of formulated feed in each treatment.

\begin{tabular}{ccc}
\hline $\mathrm{N}^{\circ}$ & Content & Percentage \\
\hline 1 & Water & 8.36 \\
2 & Crude Protein (\%) & 23.16 \\
3 & Crude fat (\%) & 6.27 \\
4 & Crude fiber (\%) & 0.47 \\
5 & NFE (\%) & 45.69 \\
6 & Ash (\%) & 16.05 \\
7 & Energy (Kcal/kg) & 4907 \\
\hline Description: Analysis & Results of \\
Livestock Feed Chemistry Laboratory \\
Faculty of Animal Science, \\
Hasanuddin University (2016).
\end{tabular}

\subsection{Treatments and Experimental Design}

The research design adopted a completely randomized design (CRD) with 3 treatments and 3 replicates. Each of the treatments applied the combination of artificial feed and fresh marine algae Gracilaria sp. Each treatment encompassed: A. $25 \%$ artificial feed $+75 \%$ fresh marine algae, B. $50 \%$ artificial feed $+50 \%$ fresh marine algae, C. $75 \%$ artificial feed $+25 \%$ fresh marine algae.

\subsection{Observed Parameters}

Relative growth was calculated with the following formula (Watanabe et al., 1983) (Equation 1):

$$
\mathrm{RG}=\frac{W t-W 0}{W 0} \times 100
$$

Where:

$$
\begin{aligned}
& \mathrm{RG}=\text { Relative Growth }(\%) \\
& \mathrm{W}_{\mathrm{o}}=\text { initial average weight }(\mathrm{g}) \\
& \mathrm{W}_{\mathrm{t}}=\text { final average weight }(\mathrm{g})
\end{aligned}
$$

The survival rate of abalone was observed at the initial and the final period of the experiment and was measured using the following formula (Effendie, 2002) (Equation 2):

$$
\mathrm{S}=\frac{N t}{N 0} \times 100 \%
$$

Where:

$$
\begin{aligned}
& \mathrm{S}=\text { survival rate }(\%) \\
& \mathrm{N}_{\mathrm{t}}=\text { total survived post-larvae abalone }(\mathrm{pcs}) \\
& \mathrm{N}_{0}=\text { total Abalone Juvenile larvae stocked (pcs) }
\end{aligned}
$$




\subsection{Data Analysis}

All data were converted to mean values and were analyzed by one-way analysis of variance (ANOVA). The Software of SPSS Windows v.20 was employed to identify the differences among the treatments. Any significant effect observed in the experimental parameters will be further analyzed by conducting the least significant difference at a significance level of 5\%.

\section{RESULT AND DISCUSSION}

The data of average relative growth in each treatment is presented in Table 3.

Table 3. Relative growth resulted from each treatment.

\begin{tabular}{cc}
\hline Treatment & Relative Growth $(\%)$ \\
\hline A & $2.48 \pm 0.10^{\mathrm{a}}$ \\
B & $2.35 \pm 0.07^{\mathrm{a}}$ \\
C & $2.36 \pm 0.12^{\mathrm{a}}$ \\
\hline
\end{tabular}

Description: A. $25 \%$ artificial feed $+75 \%$ fresh marine algae, B. $50 \%$ artificial feed $+50 \%$ fresh marine algae, C. $75 \%$ artificial feed $+25 \%$ fresh marine algae; Description: Superscript letters within the same row indicated no significant effect from the treatment $(\mathrm{P}>0,05)$.

Analysis of Variance indicated that the combination of artificial feed and fresh marine algae Gracilaria sp had no significant effect on the relative growth of Abalone Juvenile larvae $(\mathrm{P}>0.05)>$. This indicated that the combination of artificial diet and fresh marine algae contributed to an equal relative growth of abalone larvae. The relative growth of Abalone Juvenile larvae in each treatment did not indicate any significant effect. The equal results of relative growth were most probably caused by a number of positive factors including good water quality and good nutrient absorption from the combination of artificial feed and fresh marine algae Gracilaria sp. According to Allen et al. (2006), the supplementation of Gracilaria $s p$ in abalone feed may serve as a stimulant for a more effective feed compared to the commercial feed. Feeding the abalone with a combination of $75 \%$ Gracilaria $s p$ and $75 \%$ artificial feed seemed to be absorbed effectively. According to Capinpin and Corre (1996), there are three factors affecting the abalone preference to the algae. These included the metabolite compounds (Paul et al., 2006; Winter and Estes, 1992), the morphology and the texture of algae, as well as the necessary nutrients for abalone growth. The supplementation of Gracilaria sp. as feed could encourage the appropriate growth for abalone H. squamata farming (Hadijah, 2017; Hadijah et al., 2020). In addition, the rearing circumstance significantly affects abalone growth. One of the parameters is water salinity (Boamah et al., 2020; Kong et al., 2017).

The observation result of abalone's survival rate is presented in Figure 4.

The results of ANOVA indicated that the combination of artificial feed and marine algae Gracilaria $s p$ did not affect the survival rate of Abalone juvenile larvae significantly ( $\mathrm{P}>0.05)$. The absence of a significant difference among the treatments demonstrated the complementary roles between fresh natural diet and artificial feed despite the percentage difference. Although no significant difference in absolute and relative growth, the ranges of abalone survival rate by the end of the experiment were descriptively optimal, accounting for $97-99 \%$. 


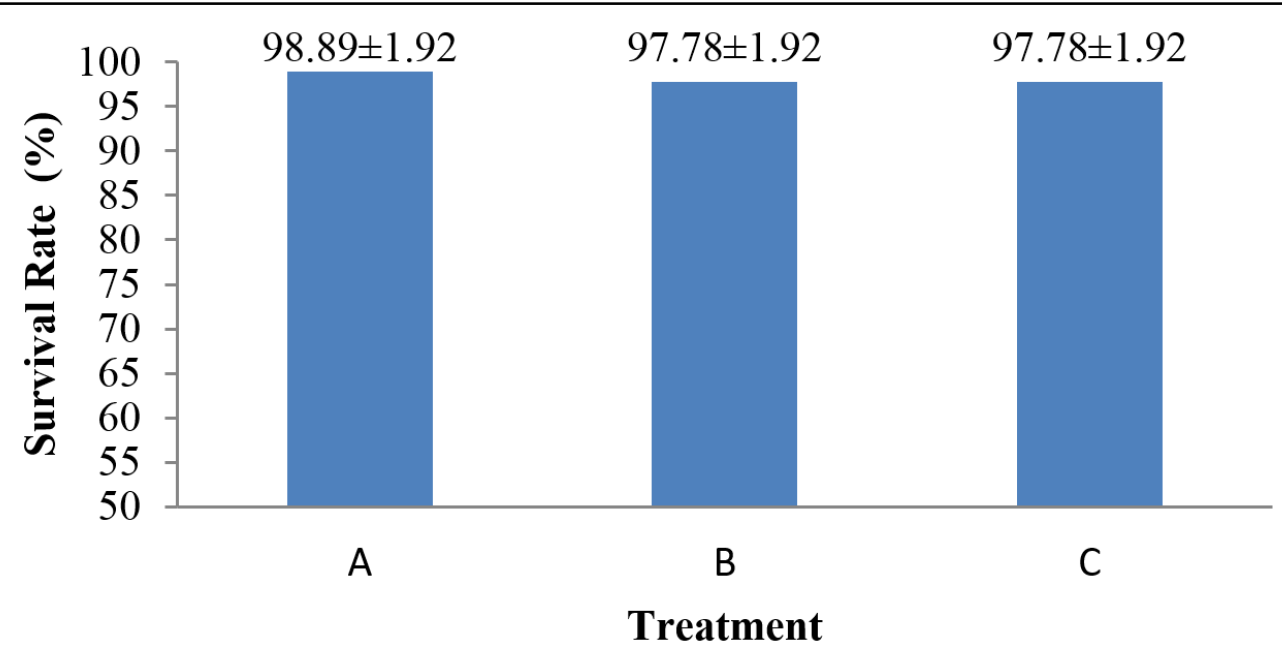

Figure 4. Abalone's Survival Rate in Each Treatment.

By understanding the abalone's natural feeding behavior as an herbivore epiphyte grazer adhering to the substrates, it is acceptable for the abalone to consume a low-protein feed. According to Patadjai et al. (2009), the protein required by abalone ranged from $17-27 \%$. Fleming et al. (1996) confirmed that the properly formulated feed for abalone should contain high protein content (20-50\%) and carbohydrate (30-60\%), low lipid (1.5-5.3\%), and fiber (2$6 \%$ ). The nutritional content of the experimental feed in this study (Table 2) was considered appropriate to support the abalone survival rate. Coote et al. (2000) confirmed that the crude protein required by abalone ranges from $27-40 \%$ The use of dried macroalgae flour as feedstuff in a formulated feed for abalone could become a practical option (Viera et al., 2012; O'Mahoney et al., 2014). Results from different studies indicated that Abalone Juvenile larvae could consume pelletized formulated feed and have optimal growth and survival rates when supplied with fresh feed (Bautista-Teruel et al, 2003; Patadjai et al., 2009). The substitute feed from macroalgae such as $U$. pertusa flour could substitute soy and fish meal as a protein source in formulated feed for juvenile Halitos asinine (Santizo-Taan et al., 2020).

Abalones fed with formulated feed responded positively with an optimal survival rate. This is connected with the feedstuff composition of formulated feed that sustains growth, including protein, balanced amino acid, fat, carbohydrate, fiber, vitamin, mineral, binder, and attractant (Daniel, 2018). An artificial feed could be produced from alternative local feedstuff and is capable of improving the potential of marine animal growth, such as white leg juvenile shrimp (Zainuddin et al., 2020) or abalone. According to Hadijah et al. (2020), different percentages of marine algae supplementation contributed to a similar response to growth, survival rate, and tropical abalone soft tissue's chemical composition. In addition, protein composition also indicated an increase after feeding on artificial feed. A number of carbohydrate sources that can be used in artificial feed included starch, corn starch, rice flour and wheat flour (Freeman, 2001). Currently, there are various commercial feeds available in the market containing $20-50 \%$ protein, $30-60 \%$ carbohydrates, $1.5-5.3 \%$ fat, and $0-3 \%$ crude fiber (Fleming et al., 1996). Bautista-Teruel et al. (2003) reported that $H$. asinina supplied with formulated feed showed a positive response of growth compared to abalone supplied with natural feed.

Coote et al. (2000) reported that increasing feed protein content to $27 \%$ could optimize the growth of abalone H leveigata. In this experiment, the supplemented animal protein was a fish meal, shrimp cephalothorax flour, and crab gonad meal, while the plant protein source was obtained from soybean meal.

The absence of significant difference in the Abalone juvenile larvae survival rate indicated that the combination of artificial feed and fresh feed contributed equal output of survival rates. 
This was because of the feed nutritional content that could sustain the Abalone juvenile larvae survival. High survival growth of Abalone juvenile larvae was stimulated by the available and sufficient nutrients such as protein, carbohydrates, fat in the supplied feed for abalone larvae. Some research also suggests that although abalones prefer to forage marine algae, frequent marine algae supplementation during the rearing period may result in lower and heterogenous growth (Stickney, 2000; Priyambodo et al., 2005).

\section{CONCLUSION}

The results of the study indicated that the use of a combined artificial feed with fresh marine algae (Gracilaria sp.) had no significant effect on relative growth and survival rates of Haliotis squamata. Although feed treatment did not significantly affect the relative growth and survival rate, descriptively, Treatment A (25\% artificial feed $+75 \%$ fresh marine algae) contributed to the most optimal relative growth and the survival rate compared to Treatments $\mathrm{B}(50 \%$ artificial feed $+50 \%$ fresh marine algae) and C (75\% artificial feed $+25 \%$ fresh marine algae).

\section{ACKNOWLEDGEMENT}

The authors would like to express their gratitude to the Directorate of Research and Community Engagements, Ministry of Research, Technology, and Higher Education of Indonesia that funded this research through STRANAS Research program in 2016. The authors also would like to thank to the local community of Lae-Lae Island, South Sulawesi, Indonesia for participating to this program.

\section{REFERENCES}

ABARES. Australian fisheries and aquaculture statistics 2016. Canberra City, 2017.

ALLEN, V. J.; MARSDEN, I. D.; RAGG, N. L. C.; GIESEG, S. The effects of tactile stimulants on feeding, growth, behaviour, and meat quality of cultured Blackfoot abalone, Haliotis $\begin{array}{lllll}\text { iris. Aquaculture, } & \text { v. 257, } 2906 .\end{array}$ https://doi.org/10.1016/j.aquaculture.2006.02.070

ARDI, I.; SETIADI, E.; RASIDI, R.; PRANOWO, W. S. The grow-out of abalone (Haliotis squamata) at different shelter shapes on growth and survival and its marine environmental influences at Lembongan Bay coastal waters. Proceedings IOP Conference Series: Earth and Environmental Science, v. 441, 2020. 10.1088/1755-1315/441/1/012001

BANSEMER, M. S.; QIN, J. G.; HARRIS, J. O.; HOWARTH, G. S.; STONE, D. A. J. Nutritional requirements and use of macroalgae as ingredients in abalone feed. Reviews in Aquaculture, v. 8, n. 2, p. 121-135, 2016. https://doi.org/10.1111/raq.12085

BAUTISTA-TERUEL, M. N.; FERMIN, A. C.; KOSHIO, S. S. Diet development and evaluation for juvenile abalone, Haliotis asinina: animal and plant protein sources. Aquaculture, v. 219, n. 1-4, p. 645-653, 2003. https://doi.org/10.1016/S00448486(02)00410-6

BAUTISTA-TERUEL, M. N.; MILLAMENA, O. M. Diet development and evaluation for juvenile abalone, Haliotis asinina: Protein/energy levels. Aquaculture, v. 178, p. $117-$ 126, 1999. https://doi.org/10.1016/S0044-8486(99)00121-0 
BOAMAH, G. A.; WANG, T.; CHOWDHURY, I. A.; HUANG, M.; XU, C.; KE, C.; YOU, W. Sub-low salinity impact on survival, growth and meat quality of the Pacific abalone (Haliotis discus hannai) and hybrids. Aquaculture Research, v. 51, n. 12, p. 5184-5193, 2020. https://doi.org/10.1111/are.14856

BROWN, M. R.; SIKES, A. L.; ELLIOTT, N. G.; TUME, R. K. Physicochemical factors of abalone quality: A review. Journal of Shellfish Research, v. 27, n. 4, p. 835-842, 2008. https://doi.org/10.2983/0730-8000(2008)27[835:PFOAQA]2.0.CO;2

CHOJNACKA, K. Biologically Active Compounds in Seaweed Extracts - the Prospects for the Application. The Open Conference Proceedings Journal, v. 3, 2012. http://dx.doi.org/10.2174/1876326X01203020020

CAPINPIN, E. C.; CORRE, K. G. Growth rate of the Philippine abalone, Haliotis asinina fed an artificial diet and macroalgae. Aquaculture, v. 144, p. 81-89, 1996. https://doi.org/10.1016/S0044-8486(96)01332-4

COOK, P. A. The worldwide abalone industry. Modern Economy, v. 5, n. 13, p. 1181-1186, 2014. https://dx.doi.org/10.4236/me.2014.513110

COOTE, T. A.; HONE, P. W.; VAN BARNEVELD, R. J.; MAGUIRE, G. B. Optimal protein level in a semipurified diet for juvenile greenlip abalone Haliotis laevigata. Aquaculture Nutrition, v. 6. n. 4, p. 213-220, 2000. https://doi.org/10.1046/j.13652095.2000.006004213.x

DANIEL, N. A review on replacing fish meal in aqua feeds using plant protein sources. International Journal of Fisheries and Aquatic Studies, v. 6, n. 2, p. 164-179, 2018.

EFFENDIE, M. I. Biologi Perikanan. Yokyakarta, 2002.

FLEMING, A. E.; VAN BARNEVELD, R. J.; HONE, P. W. The development of artificial diets for abalone: A review and future directions. Aquaculture, v. 140, n. 1-2, p. 5-53, 1996. https://doi.org/10.1016/0044-8486(95)01184-6

FREEMAN, K. A. Aquaculture and related biological attributes of abalone species in Australia - a review. North Beach: Western Australia Marine Research Laboratories, 2001.

GALLARDO, W. G.; BUEN, S. M. A. Evaluation of mucus, Navicula, and mixed diatoms as larval settlement inducers for the tropical abalone Haliotis asinina. Aquaculture, v. 221, n. 1-4, p. 357-364, 2003. https://doi.org/10.1016/S0044-8486(03)00121-2

GIRI, N. A.; MARZUQI, M.; ASTUTI, N. W. W.; ANDRIYANTO, W.; RUSDI, I.; ANDAMARI, R. Evaluasi bahan baku pakan dan pengembangan pakan buatan untuk budidaya pembesaran abalon (Haliotis squamata). Journal Riset Akuakultur, v. 10, n. $3,2015$.

GRANDIOSA, R. Increasing awareness of abalone culture to support sustainable aquaculture in Indonesia. Global Scientific Journals, v. 8, n. 6, p. 315-321, 2020.

GRUENTHAL, K. M. Conservation genetics of California abalone species. 2007. 228f. PhD (Dissertation) - University of California, San Diego, 2007.

HADIJAH. Effect of natural feed on feed consumption level and feed conversion ratio of tropical abalone Haliotis asinina on sea cage. Applied Mechanics and Materials, v. 862, p. 121-126, 2017. http://dx.doi.org/10.4028/www.scientific.net/AMM.862.121 
HADIJAH, S. Manajemen Pemberian Pakan Alami (Ulva sp.) Terhadap Tingkat Kematangan Gonad Abalon (Haliotis squamata) Di Balai Produksi Induk Udang Unggul Dan Kekerangan (BPIU2K) Karangasem, Bali. 2015. Thesis - Universitas Airlangga, Airlangga, 2015

HADIJAH, S. A.; ZAINUDDIN, O. dan. Distribusi kelimpahan dan hubungan panjang berat abalon (Haliotis asinina) yang tertangkap di perairan Pulau Badi Kabupaten Pangkep. 2007. Thesis (Doctorate degree) - Lembaga Penelitian Universitas, Makassar, 2007.

HADIJAH, S. A.; ZAINUDDIN, O. dan. Kajian aspek bioekologi reproduksi dan teknologi pembenihan abalon (Haliotis asinina). TORANI Journal of Fisheries and Marine Science, v. 18, n. 4, p. 286-294, 2008.

HADIJAH, S. B.; ZAINUDDIN, E. V. The influence of substrate to larval settlement of the tropical abalone (Haliotis asinina). Modern Applied Science, v. 9, n. 1, p. 184-188, 2014. https://doi.org/10.5539/mas.v9n1p184

HADIJAH; ZAINUDDIN, Z.; AQMAL, A.; BANIN, D. K. The effect of marine algae (Gracilaria verrucosa) formulated feed on the growth rate, survival rate and chemical composition of abalone (Haliotis squamata) reared in marine submersible cages. Aquaculture, Aquarium, Conservation \& Legislation; Cluj-Napoca, v. 13, n. 5, p. 2558-2566, 2020.

HADIJAH; ZAINUDDIN, Z. et al. Tingkat kelangsungan hidup abalon tropis Haliotis asinina yang dipelihara pada kurungan dasar laut. Ecosystem, v. 15, n. 2, p. 233-244, 2015.

HWANG, E. K.; HWANG, I. K.; PARK, E. J.; GONG, Y. G.; PARK, C. S. Development and cultivation of F2 hybrid between Undariopsis peterseniana and Undaria pinnatifida for abalone feed and commercial mariculture in Korea. Journal Applied Phycology, v. 26, p. 742-752, 2014. https://doi.org/10.1007/s10811-013-0164-7

KEMP, J. O. G.; BRITZ, P. J.; TOLEDO AGÜERO, P. H. The effect of macroalgal, formulated and combination diets on growth, survival and feed utilisation in the red abalone Haliotis $\begin{array}{llllll}\text { rufescens. } & \text { Aquaculture, } & \text { v. 448, }\end{array}$ https://doi.org/10.1016/j.aquaculture.2015.06.016

KONG, N.; LIU, X.; LI, J.; MU, W.; LIAN, J.; XUE, Y.; LI, Q. Effects of temperature and salinity on survival, growth and DNA methylation of juvenile Pacific abalone, Haliotis discus hannai Ino. Chinese Journal of Oceanology and Limnology, v. 35, n. 5, p. 12481258, 2017. https://doi.org/10.1007/s00343-016-5185-z

LI, L.; ONG, M. C. A preliminary study of a rigid semi-submersible fish farm for open seas. In: INTERNATIONAL CONFERENCE ON OFFSHORE MECHANICS AND ARCTIC ENGINEERING - OMAE, 36., Trondheim, 2017. Proceedings[...] ASME, 2017. https://doi.org/10.1115/OMAE2017-61520

O’MAHONEY, M.; RICE, O.; MOUZAKITIS, G.; BURNELL, G. Towards sustainable feeds for abalone culture: Evaluating the use of mixed species seaweed meal in formulated feeds for the Japanese abalone, Haliotis discus hannai. Aquaculture, v. 430, p. 9-16, 2014. https://doi.org/10.1016/j.aquaculture.2014.02.036

OMAR, A.; BIN, S.; LITAAY, M.; ANWAR, N. The occurrence of tropical abalone (Haliotis spp) at reef flat of Bonetambu Island, Makassar. TORANI Journal of Fisheries and Marine Science, v. 16, n. 2, p. 142-147, 2006. 
PACKER, M. A.; HARRIS, G. C.; ADAMS, S. L. Food and Feed Applications of Algae. In: BUX, F.; CHISTI, Y. (eds.). Algae Biotechnology. Springer, Cham., 2016. https://doi.org/10.1007/978-3-319-12334-9_12

PALUMBI, S. R. Population genetics, demographic connectivity, and the design of marine reserves. Ecological Applications, v. 13, n. 1, 2003. https://doi.org/10.1890/10510761(2003)013[0146:PGDCAT]2.0.CO;2

PATADJAI, A. B.; EFFENDY, I. J. et al. Uji biologis (attractability dan pertumbuhan juvenile) pakan abalone pada pengembangan pakan buatan untuk memacu pematangan gonad induk dan produksi massal abalon (Haliotis asinina) di hatchery. Jakarta: Ministry of Research and Technology, 2009.

PAUL, N. A.; DE NYS, R.; STEINBERG, P. D. Seaweed-herbivore interactions at a small scale: Direct tests of feeding deterrence by filamentous algae. Marine Ecology Progress Series, v. 323, p. 1-9, 2006. https://dx.doi.org/10.3354/meps323001

PRIYAMBODO, I. B. M.; SOFYAN, B.; SUASTIKA JAYA, Y. Produksi benih tiram abalone (Haliotis asinine) di Loka Budidaya Laut Lombok. In: SEMINAR HASIL PENELITIAN PERIKANAN DAN KELAUTAN, 2005, UGM. Proceedings[...] Yogyakarta: UGM, 2005.

SANTIZO-TAAN, R., BAUTISTA-TERUEL, M. AND MAQUIRANG, J. R. H. Enriched Ulva pertusa as partial replacement of the combined fish and soybean meals in juvenile abalone Haliotis asinina (Linnaeus) diet. Journal of Applied Phycology, v. 32, p. 741749, 2020. https://doi.org/10.1007/s10811-019-01977-5

STICKNEY, R. R. Abalone culture. California: Blackwell Scientific Publications, 2000.

VANDEPEER, M. E. Abalone Aquaculture Subprogram: Preventing summer mortality of abalone in aquaculture systems by understanding interactions between nutrition and water temperature. Adelainer: Australian Research and Development Institute (Aquatic Sciences), 2006.

VIERA, A.; COURTOIS DE VICOSE, G.; ROBAINA, L.; IZQUIERDO, M. Preliminary development of various seaweed-based diets and their suitability for abalone Haliotis tuberculata coccinea Reeve. In: INTERNATIONAL ABALONE SYMPOSIUM, 8., 2012, South Africa. Proceedings[...] Westbury: IAS, 2012.

WATANABE, T.; KITAJIMA, C.; FUJITA, S. Nutritional values of live organisms used in Japan for mass propagation of fish: A review. Aquaculture v. 34, n. 1-2, 1983. https://doi.org/10.1016/0044-8486(83)90296-X

WINTER, F. C.; ESTES, J. A. Experimental evidence for the effects of polyphenolic compounds from Dictyoneurum californicum Ruprecht (Phaeophyta: Laminariales) on feeding rate and growth in the red abalone Haliotus rufescens Swainson. Journal of Experimental Marine Biology and Ecology, v. 155, p. 263-277, 1992. https://doi.org/10.1016/0022-0981(92)90067-K

WURYANDARI, G. Menerobos batas nelayan indonesia di perairan australia: permasalahan dan prospek. Jurnal Penelitian Politik, v. 11, n. 1, p. 1-20, 2014. 
YUN, A.; JEONG, H. S.; LEE, K. W.; ANSARY, M. W. R.; CHO, S. H.; KIM, H. S.; KIM, T. Growth performance and the soft body composition of juvenile abalone, Haliotis discus, Reeve 1846, fed the extruded pellets substituting fish meal and macroalgae with tunic meal of sea squirt, Halocynthia roretzi. Aquaculture Nutrition, v. 26, n. 3, 2020. https://doi.org/10.1111/anu.13047

ZAINUDDIN; ASLAMYAH, S.; NUR, K.; HADIJAH. Substitution of sweet potato flour and cornstarch to the growth, survival rate, feed conversion ratio and body chemical composition of juvenile litopenaeus vannamei. Aquaculture, Aquarium, Conservation \& Legislation, v. 13, n. 5, p. 2497-2508, 2020. 